\title{
Availability of Groundwater Data for California, Water Year 2010
}

\section{INTRODUCTION}

The U.S. Geological Survey, in cooperation with Federal, State, and local agencies, obtains a large amount of data pertaining to the groundwater resources of California each water year (October 1September 30). These data constitute a valuable database for developing an improved understanding of the water resources of the State.

This Fact Sheet serves as an index to groundwater data for Water Year 2010. It number of wells (by county) with available water-level or water-quality data for Water Year 2010 (fig. 1) and instructions for obtaining this and other groundwater information contained in the databases of the U.S. Geological Survey, California Water Science Center.

From 1985 to 1993, data were published in the annual report "Water Resources Data for California, Volume 5. Ground-Water Data"; prior to 1985, the data were published in U.S. Geological Survey Water-Supply Papers.

\section{HYDROLOGIC CONDITIONS}

Because the geography and geology of California are so complex, groundwater conditions are difficult to summarize. Groundwater levels are affected by short- and long-term climatic conditions, groundwater withdrawals, irrigation returns, and other factors. contains a map of California showing the

\section{DATA COLLECTION}

Groundwater-resources data collected by the U.S. Geological Survey, California Water Science Center includes measurements assessing groundwater quantity and groundwater quality.

\section{WATER-LEVEL MEASUREMENTS}

Water levels were measured in many types of wells under varying conditions, using standardized methods and equipment to ensure consistent accuracy and reliability. All water levels in the California database are given in feet with reference to land-surface datum. In Water Year 2010, 8,523 discrete water-level measurements were made in 2,172 wells in the State of California. The water-level counts presented in this Fact Sheet for Water Year 2010 may not be identical to the counts presented on NWISWeb, because historical water-level data are updated as they are received.

\section{WATER-QUALITY MEASUREMENTS}

The quality of groundwater ordinarily changes slowly; therefore, one sampling event per year is sufficient to define groundwater quality in most settings. In special circumstances, such as studying the effects of artificial recharge, samples may be collected more frequently to identify the nature of rapid changes in groundwater quality. In Water Year 2010, 1,094 water-quality samples were col- lected from 685 wells and springs in the State of California.

\section{WELL-NUMBERING SYSTEM}

Wells and springs in California are assigned numbers according to their location in the rectangular system for the subdivision of public land. For example, in the number 005S012E22P001M (see well-numbering diagram), the first four characters indicate the township (T. 5 S.) and the next four characters indicate the range (R.12 E.); the two digits following the range indicate the section (sec. 22); and the letter following the section indicates the 40-acre subdivision of the section. Within each 40 -acre subdivision, the wells are numbered sequentially in the order in which they were inventoried, as indicated by the last three digits. For springs, the first of these last three digits is assigned the letter ' $\mathrm{S}$ '. The final letter indicates the baseline and meridian designation as follows: $\mathrm{H}$, Humboldt; M, Mount Diablo; S, San Bernardino. This 15-digit number is called the Local Number or State Well Number.

\section{DATA AVAILABILITY}

Current and historical water data, including real-time data, for California and the United States may be accessed directly through the USGS National Water Information Website (NWISWeb) at

\section{http://waterdata.usgs.gov/}

For more information about how to obtain data, contact

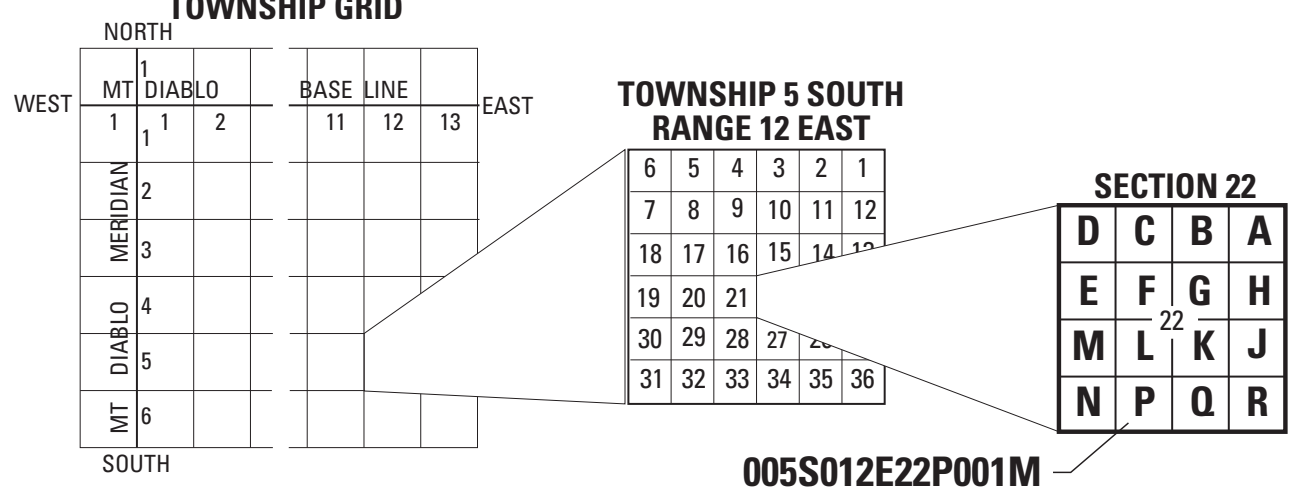

Mary Ray, 303-236-6914

(mray@usgs.gov)

or

Patricia Orlando, 916-278-3100

Public Information Officer

(porlando@usgs.gov).

Well-numbering system. 


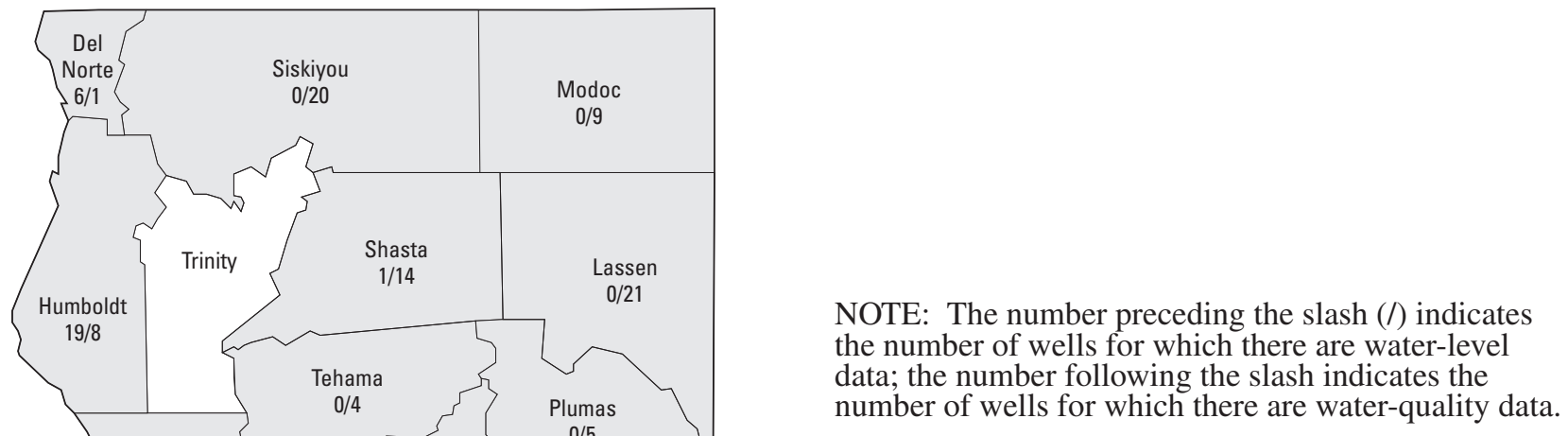

Figure 1. The number of wells for the 2010 Water Year for which data are available, by county, in the National Water Information System (NWIS) as of February 14, 2011.

For more information on water resources in California visit the USGS website at

$$
\text { http://ca.water.usgs.gov/ }
$$

or contact

Mary Ray (mray@usgs.gov)

Hydrologist

U.S. Geological Survey California Water Science Center

San Diego Projects Office

4165 Spruance Road, Suite 200

San Diego, CA 92101 